\title{
Determination of endogenous nitrogen associated with bacteria in ileal digesta of pigs receiving cereal-based diets with or without fish meal and various fibre supplements by using a simple ${ }^{15} \mathrm{~N}$-dilution technique*
}

\section{J. Bartelt ${ }^{1}$,W. Drochner ${ }^{2}$, K.-P. Götz ${ }^{3}, J$. Szakacz ${ }^{4}$, Z. Cerešňáková ${ }^{4}$ and $\mathrm{A}$. Sommer ${ }^{4}$}

\author{
'Department of Animal Nutrition, Free University of Berlin \\ Brümmerstr: 34, 14195 Berlin, Germany \\ ${ }^{2}$ Department of Animal Nutrition, Hohenheim University \\ Emil-Wolff-Str: 10, 70599 Stuttgart, Germany \\ ${ }^{3}$ Department of Crop Science, Humboldt University Berlin \\ Albrecht-Thaer-Weg 5, 14195 Berlin, Germany \\ ${ }^{4}$ Research Institute of Animal Production \\ Hlohovská 2, 94992 Nitra, Slovakia
}

(Received 19 February 1999; accepted 5 July 1999)

\begin{abstract}
Four Göttinger miniature pigs and five domestic pigs (Landrace) of similar body weight fitted with an ileocaecal re-entrant cannula were given each a ccreal-based diets with or without fish meal (Treatments 1 and 2). The diets contained increasing levels of partially hydrolysed straw meal and pectin $(2: 1 \mathrm{w} / \mathrm{w})$. On day 3,5 and 7 after the last administration of ${ }^{15} \mathrm{NH}_{4} \mathrm{Cl}$ given with the diets during five days the ileal flow of endogenous nitrogen $(\mathrm{N})$ was measured using the atom $\%{ }^{15} \mathrm{~N}$ excess in urinary $\mathrm{N}$ as indicator for that in endogenous $\mathrm{N}$. The ${ }^{15} \mathrm{~N}$-enrichments in urinary $\mathrm{N}$, in trichloroacctic acid (TCA)-soluble $\mathrm{N}$ of blood plasma as well as in TC $\mathrm{A}$-soluble and -preciptable $\mathrm{N}$ in the pancreas and small intestine were nearly the same. Furthermore, the contribution of endogenous $\mathrm{N}$ to total, TCA-preciptable and bacterial $\mathrm{N}$ of ilcal digesta was not affected by the three collection periods. Urinary $\mathrm{N}$ seems to be the easiest accessible and valid indicator for determination of the endogenous $\mathrm{N}$ under these experimental conditions. Neither the fibre supplements nor the
\end{abstract}

\footnotetext{
- This work was part of the project Ba 1388/1-1 financially supported by the Deutsche Forschungsgemeinschaft (DFG)
} 
$\mathrm{N}$ intake affected the daily ileal flow of endogenous $\mathrm{N}$. Contrary to total bacterial $\mathrm{N}$, the ileal flow of bacterial $\mathrm{N}$ of endogenous origin was not affected by the level of protein intake. The contribution of endogenous $\mathrm{N}$ associated with bacteria to total endogenous $\mathrm{N}$ ranged between 0.43 to 0.56 (Treatment 1 ) and 0.40 to 0.53 (Treatment 2). On the other side, the proportion of endogenous $\mathrm{N}$ in bacterial $\mathrm{N}$ increased from 0.48 to 0.57 (treatment 1 ) up to 0.56 to 0.79 (Treatment 2). It is concluded that endogenous $\mathrm{N}$ represents an easily available $\mathrm{N}$ source for bacterial protein synthesis at both levels of $\mathrm{N}$ intake.

KEY WORDS: pig, endogenous protein, ileum, bacterial $\mathrm{N},{ }^{15} \mathrm{~N}$-isotope dilution technique

\section{INTRODUCTION}

The ${ }^{15} \mathrm{~N}$-isotope dilution technique has proved to be a widespread approach to distinguish between gut endogenous and dietary nitrogen in ileal digesta of pigs fed protein-containing diets (De Lange et al., 1990; Huisman et al., 1992; Makkink et al., 1997; Grala et al., 1998). This method is also used for evaluation of antinutritional factors, such as soyabean trypsin inhibitors and lectins (Scluulze, 1994) or tannins (Jansman et al., 1995), as well as of neutral detergent fibre (Schulze et al., 1995) to determine the amount of endogenous $\mathrm{N}$ in the ileal digesta. The techniques applied in these studies involve a continuous intravenous infusion of a $\left[{ }^{15} \mathrm{~N}\right]$-lcucine solution for several days and the estimation of the atom- $\%{ }^{15} \mathrm{~N}$-excess in total $\mathrm{N}$ in ileal digesta and in TCA-soluble $\mathrm{N}$ of blood plasma during the last days of the infusion period. Regarding the assumption that ${ }^{15} \mathrm{~N}$-excess $\left({ }^{15} \mathrm{~N}\right)$ is uniformly transferred to other amino acids from transaminated $\left[{ }^{15} \mathrm{~N}\right]$-leucine, the ${ }^{15} \mathrm{~N}$-enrichment in endogenous $\mathrm{N}$ secreted into the digestive tract should be indicated by the TCA-soluble N fraction of blood plasma. Souffrant et al. (1993), Lien et al. (1997a,b) as well as Leterme et al. (1998) showed, however, that the ${ }^{15} \mathrm{~N}$-accumulation in the TCA-soluble $\mathrm{N}$ of blood plasma is a poor indicator of the ${ }^{15} \mathrm{~N}$-enrichment of the secretions into the gastrointestinal tract. Simon ct al. (1987) and Bartelt et al. (1994) used an alternative ${ }^{15} \mathrm{~N}$-isotope dilution technique using orally administered ${ }^{15} \mathrm{~N}$-labelled ammonium salts. The atom $\%{ }^{15} \mathrm{~N}$ ' in endogenous $\mathrm{N}$ of ileal digesta was assumed to be similar to that in urinary $\mathrm{N}$ three days after the last administration of isotope. However, the accuracy of ${ }^{15} \mathrm{~N}$-enrichment in urinary $\mathrm{N}$ as an indicator for the labelling of endogenous $\mathrm{N}$ as well has been described to be dubious by Herrmann et al. (1986) or Schulze (1994). An additional methodical aspect of the ${ }^{15} \mathrm{~N}$-isotope dilution technique is the role of bacteria in the small intestine. Studies by Bergner ct al. (1986) demonstrated a remarkable incorporation of endogenous ${ }^{15} \mathrm{~N}$ ' into bacterial protein of the small intestine of pigs following a continuous parenteral infusion of ${ }^{15} \mathrm{~N}$-labelled urea. Therefore, a proportion of bacterial nitrogen is a constituent of endogenous nitrogen in ileal digesta measured by the ${ }^{15} \mathrm{~N}$-isotope dilution technique. Consequently, different activities of 
bacteria in the proximal intestine caused by feeding level or diet composition may affect the amount of endogenous $\mathrm{N}$ at the distal ileum. Especially, the role of dietary fibre and protein level is not well known at present. The objectives of the present study were to examine the effects of different protein levels and increasing supplements of partially hydrolysed straw meal and pectin, as easily fermentable fibre sources, on endogenous $N$ associated with bacteria at the distal ileum using a simple ${ }^{15} \mathrm{~N}$-isotope dilution technique which included oral ${ }^{15} \mathrm{~N}$-labelling with ${ }^{15} \mathrm{NH}_{4} \mathrm{Cl}$ and the use of urinary $\mathrm{N}$ as indicator pool for endogenous $\mathrm{N}$. Results presented in this report are the sequel of experiments with miniature pigs carried out for estimation of ileal endogenous $\mathrm{N}$-flow as affected by different fibre and $\mathrm{N}$ intake (Bartelt et al., 1994).

\section{MATERIAL AND METHODS}

Animals, diets, feeding

Four male Göttinger miniature pigs of about $29 \mathrm{~kg}$ mean body weight (BW), 7 month -1 year old, were used in the first part of the experiment. For comparison in the second part of the study five domestic pigs (Landrace) were used of similar body weight $(23 \mathrm{~kg})$. Each animal was fitted with an ileocaecal re-entrant cannula using the postimplantative distension-technique of an enrolled tube-foot as described by Drochner ct al. (1997). The animals were under continuous veterinary health control. After implantation of the cannulas the pigs were housed in metabolic cages and tied with a shoulder belt.

The higher level of protein intake (Treatment 1) was realised by a wheat-maize based basal diets with fish meal. Two miniature pigs and two domestic pigs reccived these basal diets during the first and second part of experiment, respectively. The basal diets which contained only wheat and maize as the sole sources of protein (Treatment 2) were fed to two miniature pigs and three domestics pigs during the first and second part of experiment, respectively. In both treatments, the basal diets were supplemented with graded levels of wheat straw meal and pectin $(2: 1 \mathrm{w} / \mathrm{w})$. The wheat straw meal was treated with $\mathrm{HCl}$ and steam and neutralised with $\mathrm{Ca}(\mathrm{OH})_{2}$ according to Bergner and Betzin (1979). It was then dried and finely ground. The experimental design is shown in Table 1.

The formulation of the basal dicts, their chemical composition and that of partially hydrolysed straw meal are presented in Table 2 . Duc to the fibre supplements, the concentrations of neutral detergent fibre in the diets of Treatments 1 and 2 increased from 103 to $144 \mathrm{~g} / \mathrm{kg} \mathrm{DM}$ and from 135 to $161 \mathrm{~g} / \mathrm{kg} \mathrm{DM}$, respectively. The corresponding concentrations of acid detergent fibre were 31 to $82 \mathrm{~g} / \mathrm{kg}$ $\mathrm{DM}$ and 59 to $90 \mathrm{~g} / \mathrm{kg}$ DM. The same batches of fecd components were not avail- 
TABLE 1

Experimental design

\begin{tabular}{|c|c|c|c|c|c|c|c|c|c|}
\hline \multirow[b]{2}{*}{ Fibre supplement* } & \multicolumn{4}{|c|}{$\begin{array}{c}\text { Treatment } 1 \\
\text { wheat-maize diets } \\
\text { with fish meal } \\
(156-186 \mathrm{~g} \mathrm{CP} / \mathrm{kg} \mathrm{DM})\end{array}$} & \multicolumn{4}{|c|}{$\begin{array}{c}\text { Treatment } 2 \\
\text { wheat-maize diets } \\
\text { without fish meal } \\
(106-128 \mathrm{~g} \mathrm{CP} / \mathrm{kg} \mathrm{DM})\end{array}$} & \multirow[b]{2}{*}{150.0} \\
\hline & 0 & 37.5 & 75.0 & 112.5 & 0 & 37.5 & 75.0 & 112.5 & \\
\hline Animal No. & 1 & 2 & 3 & 4 & 5 & 6 & 7 & 8 & 9 \\
\hline Breed** & M & M & $\mathrm{L}$ & $\mathrm{L}$ & $\mathrm{L}$ & $\mathrm{L}$ & M & $M$ & $\mathrm{~L}$ \\
\hline Part of trial & 1 & 1 & 2 & 2 & 2 & 2 & 1 & l & 2 \\
\hline
\end{tabular}

* partially hydrolysed straw meal and pectin $(2: 1 \mathrm{w} / \mathrm{w})$ in $\mathrm{g} / \mathrm{kg}$ basal dicts

** $\mathrm{L}=$ Landrace $\mathrm{M}=$ Miniature pig

TABLE 2

Formulation and chemical composition of the basal diets and hydrolysed straw meal

\begin{tabular}{|c|c|c|c|}
\hline & \multicolumn{2}{|c|}{ Basal diet } & \multirow{2}{*}{$\begin{array}{c}\text { Partially hydrolysed } \\
\text { straw meal** }\end{array}$} \\
\hline & with fish meal & without fish meal & \\
\hline \multicolumn{4}{|l|}{ Ingredients, $\mathrm{g} / \mathrm{kg}$} \\
\hline wheat & 660 & 730 & \\
\hline maize & 220 & 250 & \\
\hline fish meal & 100 & - & \\
\hline vitamin/mineral mixture* & 20 & 20 & \\
\hline \multicolumn{4}{|l|}{ Analyses, g/kg DM*** } \\
\hline dry matter $(g / \mathrm{kg})$ & 881 & 888 & 883 \\
\hline crude protein $(\mathrm{N} \times 6.25)$ & 186 & 119 & 35 \\
\hline crude fat & 33 & 23 & 14 \\
\hline ash & 52 & 36 & 97 \\
\hline crude fibre & 19 & 26 & 410 \\
\hline neutral detergent fibre & 103 & 135 & 558 \\
\hline acid detergent fibre & 31 & 59 & 533 \\
\hline
\end{tabular}

* Phoscana $18 \mathrm{Z}$, Fa. Karl Wolpers, Hildesheim provided the following: (g/kg of dict) Ca, 4.3; P, 1.6: $\mathrm{Na} \mathrm{1.0;} \mathrm{Mg}, 0.1(\mathrm{mg} / \mathrm{kg}$ of diet) vitamin E, 20; niacin, 10; pantothenic acid, 5: riboflavin, 4: pyridoxine, 2 ; thiamine, $1 ; \mathrm{Zn}, 100 ; \mathrm{Fe}, 80 ; \mathrm{Mn}, 60 ;$ choline chloride, $40 ; \mathrm{Cu}, 14 ; \mathrm{J}, 1(\mu \mathrm{g} / \mathrm{kg}$ of diet) vitamin $A, 240$; vitamin $D_{2}, 25$; vitamin $B_{12}, 20$; biotin, $40 ; S c, 200$

** average chemical composition of two charges for both parts of experiment

*** analysed basal diet with fish meal fed in the first part of the experiment; analysed basal diet without fish meal fed in the second part of the experiment 
able for the two separate parts of study. Therefore, the contents of nutrients in the basal diets of both treatments varied to a certain extent. In both treatments, one animal was fed one level of partially hydrolysed straw meal and pectin. The diets were fed in equal portions at 0800 and 2000 . The daily feed intake of the basal diets was $54 \mathrm{~g}$ air dried matter $/ \mathrm{kg}^{0.75} \mathrm{BW}$. Water and diets were mixed immediately before feeding $(4.3: 1 \mathrm{v} / \mathrm{w})$. Additional water was not offered.

\section{${ }^{15} \mathrm{~N}$-dilution technique}

During the first 5 days of the experiment, the animals received daily $150 \mathrm{mg}$ ${ }^{15} \mathrm{~N}^{\prime} / \mathrm{kg}^{0.75} \mathrm{BW}$, added as ${ }^{15} \mathrm{NH}_{4} \mathrm{Cl}$ (95 Atom $\%{ }^{15} \mathrm{~N}$, Chemotrade GmbH Leipzig) to the diets. Hourly urine and ileal digesta collections were performed on $\mathrm{d} 8,10$ and 12 after the first administration of the isotope over $24 \mathrm{~h}$ and pooled for $4 \mathrm{~h}$-periods for urine and digesta samples. At the same time unlabelled ileal digesta was infused hourly into the caecum. The unlabelled ileal digesta had been collected from the same animals in a preliminary period on 6 successive days for $12 \mathrm{~h}$ each. Afterwards, the unlabelled digesta was portioned in 72 equal portions. The technique of reinfusion has been described by Drochner et al. (1987). At a defined time after feeding all animals used in the second part of experiment were slaughtered on 14 of the experiment. Thereafter, samples of plasma, urine and tissues of pancreas, duodenum, ileum, liver and muscle were collected to compare the ${ }^{15} \mathrm{~N}$-enrichments. Digesta, urine, blood and tissue samples were frozen and stored at $-20^{\circ} \mathrm{C}$ until analyses.

\section{Separation of bacterial fraction}

The bacterial fraction of ileal digesta was separated by washing fresh digesta samples with a detergent solution which contained one part sodium dodecyle-sulphate solution $(34.7 \mathrm{mmol} / \mathrm{l})$ and nine parts formaldehyde solution $(116.6 \mathrm{mmol} / \mathrm{l})$ four times. After every washing procedure the samples were filtered through gauze $\left(250 \mu \mathrm{m}\right.$ mash size). Thereafter, all filtrates were frozen and stored at $-20^{\circ} \mathrm{C}$ until centrifugation. After centrifugation of the filtrate $\left(28,000 \times \mathrm{g}, 30 \mathrm{~min}, 4^{\circ} \mathrm{C}\right)$ the supcrnatant was removed. The precipitate was suspended in physiological $\mathrm{NaCl}$ solution, centrifuged again and freeze-dried.

\section{Chemical analysis}

The analyses of dry matter (DM), nitrogen, crude fibre, crude fat, ash, neutral detergent fibre (NDF) and acid detergent fibre (ADF) in diets, partially hydrolysed straw meal, digesta and urine samples were analysed using standard methods of VDLUFA (Naumann and Bassler, 1976). Ileal digesta, tissue and blood 
plasma samples were prepared for the detcrmination of the TCA-soluble and precipitable $\mathrm{N}$ fractions by precipitation with TCA solution (20\%). After centrifugation, the precipitate was washed twice with TCA solution $(7 \%)$. For the determination of the atom $\%{ }^{15} \mathrm{~N}$ ' the remaining solution of $\mathrm{NH}_{4} \mathrm{Cl}$ following titration (Kjeldahl-N analyse) was cvaporated, adjusted to a N concentration of $500 \mu \mathrm{g} / \mathrm{ml}$ and introduced into an emission spectrometer (Isonitromat 5200, Statron, Fürstenwalde, Germany). 2,6-diaminopimelic acid (DAPA) was determined in digesta samples and bacterial fractions by ion exchange chromatography after hydrolysis in $6 \mathrm{M}$ aqueous $\mathrm{HCl}$ at $110^{\circ} \mathrm{C}$ for $24 \mathrm{~h}$. Due to low amount of isolated raw bacterial fractions of miniature pigs the isolates of each animal were pooled to provide one sample for the determination of DAPA and N. These measurements were performed in five pooled isolates of each of the domestic pigs.

\section{Mathematical and statistical methods}

The contribution of endogenous $\mathrm{N}$ to total N, TCA-precipitable $\mathrm{N}$ and bacterial $\mathrm{N}$ in ileal digesta was calculated by the ratios of ${ }^{15} \mathrm{~N}$-enrichments in total $\mathrm{N}, \mathrm{TCA}$ precipitable $\mathrm{N}$ or bacterial $\mathrm{N}$ to those in urinary $\mathrm{N}$ at the same time. The bacterial $\mathrm{N}$ in ileal digesta was calculated according to the DAPA/N-ratios measured in the isolated bacterial fractions and the daily amounts of DAPA at the distal ileum. Results are given as mean \pm standard error (SE). The cffect of fibre supplements was cvaluated by the onc-way ANOVA-procedure, followed if necessary by the Tukey's test for comparison of means or by the Kruskall Wallis test for comparison of medians (inhomogeneous variances). For the comparison of the two breeds or two levels of protcin intake, the Student's $t$ - test was used. All calculations were carried out by Statgraphics ${ }^{\text {sis }}$ Plus 3.1 for Windows ${ }^{\mathrm{TM}}$.

\section{RESULTS}

All pigs consumed their allotted amount of feed within $0.5 \mathrm{~h}$. They remained healthy throughout the trial. Intestinal abnormalities as a result of cannulation were not observed post mortem.

\section{${ }^{15} \mathrm{~N}$-enrichment in different $\mathrm{N}$ pools after withdrawal of isotope}

In the present study it was found that the atom $\%{ }^{15} \mathrm{~N}^{\prime}$ in urinary $\mathrm{N}$ decreased from the first (d 8) to the third (d 12) period of collection (Tables 3 and 4). This decrease in ${ }^{15} \mathrm{~N}$-enrichment excess was paralleled by that in total and bacterial $\mathrm{N}$ of ileal digesta. Consequently, the relative contribution of endogenous $\mathrm{N}$ to total and bacterial $\mathrm{N}$ in ileal digesta did not appear to differ remarkably between the 
three periods of collection. The atom $\%{ }^{15} \mathrm{~N}$ in various body tissues as well as in blood plasma at slaughter on the day 14 of the experiment are shown in Table 5 together with values for urine collected from the bladder immediately after slaughter.

There were good agreements (or only very small differences) between the urine values and those for the TCA-soluble $\mathrm{N}$ of blood plasma and tissues of the pancreas and small intestine of animals fed diets with or without fish meal, respectively.

\section{Different fractions of nitrogen in ileal digesta}

The supply of fibre sources, the $\mathrm{N}$ intake and the amounts of different $\mathrm{N}$ fractions estimated at the distal ileum of pigs are shown in Table 6 . The differences in the amounts of $\mathrm{N}$ consumed between miniature and domestic pigs within each treatment were the result of different batches of feed components used in the two parts of the trial. In each treatment, the average daily amount of total $\mathrm{N}$ and total

TABLE 3

Atom $\%{ }^{15} \mathrm{~N}$ excess in urinary nitrogen as well as in different nitrogen fractions of ileal digesta and their endogenous proportions in pigs receiving the diets with fish meal (mean $\pm S E, n=4$ )

\begin{tabular}{|c|c|c|c|c|c|}
\hline \multirow[b]{2}{*}{ Day* } & \multicolumn{3}{|c|}{ Atom $\%{ }^{15} \mathrm{~N}$ excess } & \multicolumn{2}{|c|}{ Endogenous proportions** } \\
\hline & urine $\mathrm{N}$ & ileal digesta $\mathrm{N}$ & bacterial $\mathrm{N}$ & total $\mathrm{N}$ & bacterial $\mathrm{N}$ \\
\hline $8(3)$ & $0.69 \pm 0.017^{\mathrm{a}}$ & $0.37 \pm 0.013^{\mathrm{a}}$ & $0.37 \pm 0.017^{\mathrm{a}}$ & $0.54 \pm 0.012$ & $0.53 \pm 0.019$ \\
\hline $10(5)$ & $0.48 \pm 0.030^{b}$ & $0.24 \pm 0.016^{\mathrm{b}}$ & $0.23 \pm 0.027^{\mathrm{b}}$ & $0.51 \pm 0.011$ & $0.49 \pm 0.027$ \\
\hline $12(7)$ & $0.37 \pm 0.022^{c}$ & $0.19 \pm 0.008^{c}$ & $0.21 \pm 0.021^{b}$ & $0.51 \pm 0.009$ & $0.56 \pm 0.040$ \\
\hline
\end{tabular}

* day after the first administration of isotope; in parentheses: day after ending ${ }^{15} \mathrm{~N}$-feeding

** atom $\%{ }^{15} \mathrm{~N}$ excess in digesta or bacterial $\mathrm{N} /$ atom $\%{ }^{15} \mathrm{~N}$ excess in urinary $\mathrm{N}$

a,b,c values in the same column with different subscripts are different at $\mathrm{P}<0.05$

TABLE 4

Atom $\%{ }^{15} \mathrm{~N}$ excess in urinary nitrogen as well as in different nitrogen fractions of ileal digesta and their endogenous proportions in pigs receiving the diets without fish meal $($ mean $\pm \mathrm{SE}, \mathrm{n}=5)$

\begin{tabular}{|c|c|c|c|c|c|}
\hline \multirow[b]{2}{*}{ Day* } & \multicolumn{3}{|c|}{ Atom $\%{ }^{15} \mathrm{~N}$ excess } & \multicolumn{2}{|c|}{ Endogenous proportions** } \\
\hline & urine $\mathrm{N}$ & ileal digesta $\mathrm{N}$ & bacterial $\mathrm{N}$ & total $\mathrm{N}$ & bacterial $\mathrm{N}$ \\
\hline $8(3)$ & $0.88 \pm 0.079^{\mathrm{a}}$ & & & $0.66 \pm 0.047$ & $0.72 \pm 0.058$ \\
\hline $10(5)$ & $0.57 \pm 0.056^{b}$ & $0.36 \pm 0.031^{\mathrm{b}}$ & $0.38 \pm 0.024^{b}$ & $0.64 \pm 0.045$ & $0.68 \pm 0.030$ \\
\hline $12(7)$ & $0.46 \pm 0.048^{b}$ & $0.28 \pm 0.031^{\mathrm{b}}$ & $0.31 \pm 0.031^{\mathrm{b}}$ & $0.63 \pm 0.055$ & $0.70 \pm 0.058$ \\
\hline
\end{tabular}

* day after the first administration of isotope; in parentheses: day after ending ${ }^{15} \mathrm{~N}$ feeding

** atom $\%{ }^{15} \mathrm{~N}$ excess in digesta or bacterial $\mathrm{N} /$ atom $\%{ }^{15} \mathrm{~N}$ excess in urinary $\mathrm{N}$

a.b values in the same column with different subscripts are different at $\mathrm{P}<0.05$ 
TABLE 5

Atom-\% $\%$ N excess in various tissues, blood plasma and urine at the end of experiment on day 14 (individual values or mean $\pm \mathrm{SE}$ )

\begin{tabular}{|c|c|c|c|c|c|c|}
\hline & \multicolumn{4}{|c|}{ Diets with fish meal $(n=2)$} & \multicolumn{2}{|c|}{ Diets without fish meal $(n=3)$} \\
\hline & \multicolumn{2}{|c|}{$\begin{array}{c}\text { TCA- } \\
\text { soluble } \mathrm{N}\end{array}$} & \multicolumn{2}{|c|}{$\begin{array}{c}\text { TCA- } \\
\text { precipitable } \mathrm{N}\end{array}$} & \multirow[t]{2}{*}{$\begin{array}{c}\text { TCA- } \\
\text { soluble } \mathrm{N}\end{array}$} & \multirow[t]{2}{*}{$\begin{array}{c}\text { TCA- } \\
\text { precipitable } \mathrm{N}\end{array}$} \\
\hline & (Animal 3) & (Animal 4) & (Animal & nimal 4) & & \\
\hline Stomach & 0.28 & 0.36 & 0.28 & 0.27 & $0.30 \pm 0.044$ & $0.27 \pm 0.037^{\text {ath }}$ \\
\hline Duodenum & 0.27 & 0.36 & 0.27 & 0.29 & $0.30 \pm 0.047$ & $0.32 \pm 0.046^{\text {ith }}$ \\
\hline Ileum & 0.29 & 0.36 & 0.26 & 0.27 & $0.39 \pm 0.087$ & $0.34 \pm 0.098^{\text {ath }}$ \\
\hline Rectum & 0.35 & 0.34 & 0.25 & 0.30 & $0.33 \pm 0.057$ & $0.26 \pm 0.055^{\text {str }}$ \\
\hline M.longissimus dorsi & 0.30 & 0.35 & 0.19 & 0.22 & $0.27 \pm 0.046$ & $0.19 \pm 0.032^{i}$ \\
\hline Pancreas & 0.30 & 0.34 & 0.32 & 0.32 & $0.35 \pm 0.058$ & $0.36 \pm 0.030^{\mathrm{ath}}$ \\
\hline Liver & 0.36 & 0.41 & 0.49 & 0.56 & $0.37 \pm 0.058$ & $0.50 \pm 0.064^{\mathrm{h}}$ \\
\hline Kidncy & 0.34 & 0.35 & 0.41 & 0.37 & $0.33 \pm 0.055$ & $0.40 \pm 0.056^{\text {ath }}$ \\
\hline Blood plasma & 0.32 & 0.31 & 0.48 & 0.47 & $0.36 \pm 0.072$ & $0.45 \pm 0.071^{\text {th }}$ \\
\hline \multirow[t]{2}{*}{ Urine* } & \multicolumn{4}{|c|}{ Total N } & \multirow{2}{*}{\multicolumn{2}{|c|}{$\begin{array}{c}\text { Total N } \\
0.36 \pm 0.061^{\circ}\end{array}$}} \\
\hline & $0.35(\mathrm{Ar}$ & nimal 3) & 0.33 & nal 4) & & \\
\hline
\end{tabular}

* from the bladder

is. h values in the same column with different subscripts are different at $\mathrm{P}<0.05$

- not significantly different from the TCA-soluble and TCA-precipitable $\mathrm{N}$ of blood plasma and tissues

endogenous $\mathrm{N}$ passing through the ileum was quite variable. Nevertheless, increasing levels of fibre supplements did not affect the amounts in pigs of the same genotype. Significant lower values were observed for the miniature pigs compared to the domestic pigs. The total $\mathrm{N}$ at the distal ileum of pigs receiving the diets without fish meal was on average $22 \%$ units lower $(\mathrm{P}<0.001)$ than of pigs fed the diets with fish meal. In contrast to total $\mathrm{N}$ the values for endogenous $\mathrm{N}$ were not affected by $\mathrm{N}$ intake. Approximately $50 \%$ of endogenous $\mathrm{N}$ in all animals was TCA-precipitable.

In each treatment, increasing fibre supplements had no affect on the daily amounts of total bacterial $\mathrm{N}$ at the distal ileum in pigs of the same genotype. Significant lower values were also observed for the miniature pigs compared to the domestic pigs. In agreement with total $\mathrm{N}$ bacterial $\mathrm{N}$ in diets without fish meal was on average up to $33 \%$ units lower $(\mathrm{P}<0.001)$ than in diets with fish meal. In both treatments, the endogenous $\mathrm{N}$ associated with bacteria was also not affected by the supplements of partially hydrolysed straw meal and pectin. The amounts of bacterial $\mathrm{N}$ of endogenous origin differed between the breed $(\mathrm{P}<0.001)$ but were not affected by the $\mathrm{N}$ intake. Therefore, the contribution of bacterial $\mathrm{N}$ originating from endogenous sources to total $\mathrm{N}$ of ileal digesta was higher in Treatment 2 
TABLE 6

Daily amounts of different nitrogen fractions at the distal ileum (mean $\pm \mathrm{SE}, \mathrm{n}=3$ ) and the contribution of bacterial nitrogen of endogenous origin to total endogenous nitrogen (in parentheses)

\begin{tabular}{|c|c|c|c|c|c|c|c|c|c|c|}
\hline \multirow{3}{*}{$\begin{array}{l}\text { Animal } \\
\text { No }\end{array}$} & \multirow{3}{*}{$\begin{array}{l}\mathrm{BW} \\
\mathrm{kg}^{0.75}\end{array}$} & \multirow{3}{*}{ Treatment* } & \multirow{3}{*}{$\begin{array}{c}\text { Supplement } * * * \\
g / \mathrm{kg}\end{array}$} & \multirow{3}{*}{$\begin{array}{l}\mathrm{N} \text { intake } \\
\mathrm{mg} / \mathrm{kg}^{0.75} * \mathrm{~d}^{-1}\end{array}$} & \multicolumn{6}{|c|}{ Ileal $N$ flow $\left(\mathrm{mg} / \mathrm{kg}^{0.75} * \mathrm{~d}^{-1}\right)$} \\
\hline & & & & & \multirow[t]{2}{*}{ total N } & \multirow[t]{2}{*}{ bacterl $\mathrm{N}$} & \multicolumn{3}{|c|}{ endogenous $N$} & \\
\hline & & & & & & & total & $\begin{array}{c}\text { TCA- } \\
\text { precipitable }\end{array}$ & $\begin{array}{c}\text { associated } \\
\text { with bacteria }\end{array}$ & \\
\hline $1 \mathrm{M}^{* *}$ & 14.1 & 1 & - & 1419 & $258 \pm 10.5^{4}$ & $140 \pm 4.3^{a}$ & $129 \pm 7.5^{\mathrm{a}}$ & $67 \pm 5.7^{4}$ & $72 \pm 3.4^{4}$ & $(0.558)$ \\
\hline $2 \mathrm{M}$ & 9.0 & 1 & 37.5 & 1392 & $299 \pm 8.8^{4}$ & $110 \pm 5.5^{a}$ & $146 \pm 9.0^{a}$ & $70 \pm 10.2^{3}$ & $63 \pm 6.9^{\circ}$ & $(0.432)$ \\
\hline $3 \mathrm{~L}^{* *}$ & 10.4 & 1 & 75.0 & 1328 & $373 \pm 4.9^{\mathrm{b}}$ & $193 \pm 12.6^{\mathrm{h}}$ & $197 \pm 5.9^{h}$ & $111 \pm 3.8^{\mathrm{b}}$ & $98 \pm 5.6^{\mathrm{h}}$ & $(0.497)$ \\
\hline $4 \mathrm{~L}$ & 10.6 & 1 & 112.5 & 1344 & $389 \pm 15.7^{h}$ & $195 \pm 12.1^{\mathrm{h}}$ & $210 \pm 10.5^{\mathrm{h}}$ & $129 \pm 6.5^{h}$ & $94 \pm 12.6^{\text {ah }}$ & $(0.448)$ \\
\hline $5 \mathrm{~L}$ & 10.9 & 2 & - & 906 & $294 \pm 31.7^{r}$ & $121 \pm 15.8^{\mathrm{ub}}$ & $215 \pm 19.0^{\mathrm{h}}$ & $114 \pm 6.5^{h}$ & $96 \pm 11.5^{\mathrm{h}}$ & $(0.447)$ \\
\hline $6 \mathrm{~L}$ & 10.2 & 2 & 37.5 & 908 & $265 \pm 11.3^{h}$ & $127 \pm 4.9^{h}$ & $183 \pm 8.8^{h}$ & $104 \pm 2.1^{h}$ & $96 \pm 6.4^{h}$ & $(0.525)$ \\
\hline $7 \mathrm{M}$ & 12.6 & 2 & 75.0 & 1042 & $200 \pm 6.4^{\prime}$ & $85 \pm 3.7^{a}$ & $112 \pm 4.9^{a}$ & $51 \pm 4.4^{1}$ & $54 \pm 3.2^{4}$ & $(0.482)$ \\
\hline $8 \mathrm{M}$ & 13.5 & 2 & 112.5 & 1026 & $224 \pm 3.2^{a b}$ & $80 \pm 1.6^{a}$ & $113 \pm 8.5^{\prime \prime}$ & $48 \pm 5.3^{4}$ & $45 \pm 4.0^{4}$ & $(0.398)$ \\
\hline $9 \mathrm{~L}$ & 10.3 & 2 & 150.0 & 934 & $298 \pm 31.2^{\mathrm{uh}}$ & $120 \pm 2.8^{h}$ & $216 \pm 23.5^{\circ}$ & $121 \pm 24.4^{\mathrm{ah}}$ & $89 \pm 4.8^{h}$ & $(0.412)$ \\
\hline \multicolumn{5}{|c|}{ Effect of breed } & $P<0.001$ & $P<0.001$ & $\mathrm{P}<0.001$ & $\mathrm{P}<0.001$ & $\mathrm{P}<0.001$ & \\
\hline \multicolumn{5}{|c|}{ Effect of $\mathrm{N}$ intake } & $P<0.005$ & $P<0.001$ & NS & NS & NS & \\
\hline
\end{tabular}

* $1=$ diets with fish meal 2 = diets without fish meal

** $\mathrm{M}=$ miniature pigs; $\mathrm{L}=$ domestic pigs (Landrace)

*** partially hydrolysed straw meal and pectin $(2: 1 \mathrm{w} / \mathrm{w})$

wh $\mathrm{h}$ means or medians in the same column of treatments 1 or 2 with different superscripts are different at $\mathrm{P}<0.05$ 
compared to Treatment 1 . The values for diets 1 to 4 (Treatment 1 ) are $0.51,0.57$, $0.50,0.48$ and for diets 5 to 9 (Treatment 2) $0.79,0.76,0.64,0.56,0.74$, respectively. On the other hand, the contribution of endogenous $\mathrm{N}$ associated with bacteria to the total endogenous $\mathrm{N}$ in ileal digesta appeared to be independent of the level of $\mathrm{N}$ intake. The $\mathrm{N}$ and DAPA contents as well as the DAPA/N-ratios of isolated bacterial fractions are given in Table 7.

TABLE 7

Contents of nitrogen and 2.6-Diaminopimelic acid in isolated bacterial fractions of ileal digesta $($ mean $\pm \mathrm{SE})$

\begin{tabular}{lcc}
\hline & Miniature pigs $(\mathrm{n}=1) *$ & Domestic pigs $(\mathrm{n}=5)^{* *}$ \\
\hline Total-N, mg/g DM & 49.0 & $41.3 \pm 1.59$ \\
DAPA, mg/g DM & 1.685 & $0.920 \pm 0.098$ \\
DAPA/N, mg/g & 34.4 & 22.3 \\
N/DAPA, mg/mg & 29.1 & 44.9 \\
\hline
\end{tabular}

* pooled sample of all animals

** pooled samples of each animal

The time course of the atom $\%{ }^{15} \mathrm{~N}^{\prime}$ of bacterial $\mathrm{N}$ (relative to that in TCAprecipitable $\mathrm{N}$ ) in Treatment 2 was at all times higher than in Treatment 1 (Figure 1) during $20 \mathrm{~h}$ period on day 8,10 and 12 of the experiment.

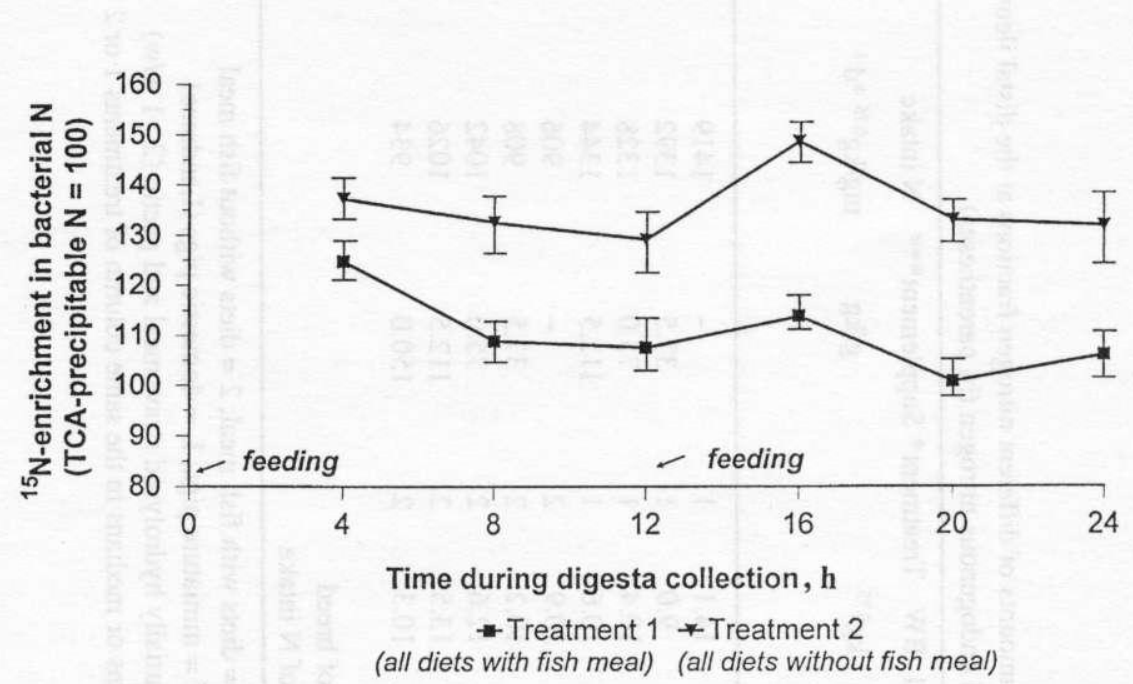

Figure 1. The time course of the average atom $\%{ }^{15} \mathrm{~N}$ excess of bacterial $\mathrm{N}$ in ileal digesta in both treatments (mean $\pm \mathrm{SE}, \mathrm{n}=12$ or 15 in Treatments 1 and 2 , respectively) 
Obviously, the time course of atom $\%{ }^{15} \mathrm{~N}$ in TCA-precipitable and bacterial $\mathrm{N}$ do not develop in a parallel course. Especially $4 \mathrm{~h}$ after feeding the atom $\%{ }^{15} \mathrm{~N}$ ' in bacterial $\mathrm{N}$ increased to a larger extent than in TCA-precipitable $\mathrm{N}$.

\section{DISCUSSION}

\section{Methodical aspects}

Taking into account that both extracellular amino acids originating from plasma or digesta and intracellular amino acids derived from intracellular protein degradation are used for protein synthesis (Simon et al., 1982, 1983) and that endogenous $\mathrm{N}$ in the gut lumen is derived from multiple precursor pools (Moughan et al., 1992), the ${ }^{15} \mathrm{~N}$-enrichment in urinary $\mathrm{N}$ was used as an indicator of that in endogenous $\mathrm{N}$ during a steady state after withdrawal of ${ }^{15} \mathrm{NH}_{4} \mathrm{Cl}$. At this time, the ${ }^{15} \mathrm{~N}$ in urine originated only from the catabolism of ${ }^{15} \mathrm{~N}$-labelled body protein. Furthermore, it can be assumed that differnt ${ }^{15} \mathrm{~N}$-enrichments in tissues caused by a different protein turnover as well as in extracellular fluids are nearly equilibrated because of isotope recycling and interorgan relationships in amino acid metabolism (Simon, 1989). In addition, the intestinal secretions contain an important proportion of non-amino acid N or urea (Buraczewska, 1979; Mosenthin and Sauer, 1991; Mosenthin et cl.,1994) which represent the predominant $\mathrm{N}$ compound in urinc. Approximately 40 to $60 \%$ of urea flux is recycled daily in the stomach and small intestine rather than in the large intestine of pigs (Bergner et al., 1986; Mosenthin et al., 1992). Also all enzymes of the urea-cycle have been demonstrated in enterocytes isolated from pre-and post-weaning pigs and relatively large amounts of urea and omithine were produced from ammonia, glutamine and arginine in a dose-dependent manner during in vitro incubations (Wu, 1995).

In the present experiment it can be seen, that all tissues which may contribute substantially to endogenous nitrogen in intestinal contents have nearly the same ${ }^{15} \mathrm{~N}$-abundances like total urinary $\mathrm{N}$ (Table 5). Only small differences in atom $\%{ }^{15} \mathrm{~N}$ ' were observed between the urinary and TCA-soluble $\mathrm{N}$ of blood plasma. Similar results were reported by Hernández et al. (1981) in rats and by Simon et al. (1987) in pigs by using the same ${ }^{15} \mathrm{~N}$-dilution technique. This observation is supported by Krawiclitzki et al. (1990) who found equal ${ }^{15} \mathrm{~N}$-enrichments in urinary and whole body $\mathrm{N}$ of a growing pig five days after withdrawal of orally administered ${ }^{15} \mathrm{NH}_{4}$-sulphate. Therefore, the ${ }^{15} \mathrm{~N}$-enrichment of urinary $\mathrm{N}$ seems to be the easiest accessible and appropriate indicator for that of endogenous $\mathrm{N}$ under the conditions of this experiment. The accuracy of the method may increase by a more uniformly labelling of the endogenous $\mathrm{N}$ pool. One possibility is the oral administration of homogenous ${ }^{15} \mathrm{~N}$-labelled yeast as performed by Wutzke et al. (1983) for calculating whole-body protein parameters in infants. 
The comparable decrease of the ${ }^{15} \mathrm{~N}$-enrichment in urinary $\mathrm{N}$ as well as of the total and bacterial $\mathrm{N}$ in ileal digesta shows that the intake of unlabelled dictary nitrogen caused a similar ${ }^{15} \mathrm{~N}$-dilution in the different $\mathrm{N}$ pools. It is concluded that steady state conditions were obtained after three days following the last administration of ${ }^{15} \mathrm{NH}_{4} \mathrm{Cl}$ in pigs given both the diets with and without fish meal. A similar atom $\%{ }^{15} \mathrm{~N}^{4}$ in bacterial and total $\mathrm{N}$ of ileal digesta was also reported by Lien et al. (1997b). This means that bacterial $\mathrm{N}$ contains the same proportion of ${ }^{15} \mathrm{~N}$-labelled endogenous $\mathrm{N}$ as the total $\mathrm{N}$ of ileal digesta, which is also presented in Tables 3 and 4.

\section{Bacterial N}

The values of bacterial $\mathrm{N}$ are calculated using the DAPA/N-ratio in the isolated bacterial fraction. A disadvantage of the use of DAPA as a bacterial marker is that its concentration varies among different species of bacteria (Dufva et al., 1982). Also, a partial breakdown of bacteria passing through the small intestine causes an enrichment in the cell walls at the distal ileum resulting in a higher DAPA/N ration. The DAP/N-ratios of bacterial fractions (Table 7) were higher compared to values of Wünsche et al. (1991) who reported 7.5 to $18.8 \mathrm{mg}$ DAPA/g bacterial N in ileal digesta of pigs fitted with ilcocaccal re-entrant cannulas. Higher values of $51.2 \mathrm{mg} \mathrm{DAP} / \mathrm{g}$ bacterial $\mathrm{N}$ were estimated by Ahrens and Kaufmann (1985) in faeces of miniature pigs. These differences could be a result of different methods for DAPA determination as well as the isolation of bacterial fractions or different populations of bacteria. In the present experiment, the differences in DAPA/Nratios of isolated bacterial fractions between the genotypes (Table 7) may be explained by different bacterial populations caused by different batches of feed components in the two separate parts of experiment. Obviously, the use of DAPA/Nratios taken from data of the literature may be a source of error for calculating bacterial $\mathrm{N}$ using DAPA as marker.

The calculated contribution of bacterial $\mathrm{N}$ to total $\mathrm{N}$ in ilcal digesta $(0.37$ to 0.54 in variant 1 and 0.36 to 0.48 in variant 2 ) are in the range of values reported by Wünsche et al. (1991) and Schulze et al. (1994). Lower values (0.23 to 0.39) were reported by Drochner (1984) in studies with miniature pigs. Similarly, Schulze et al. (1994) also reported no differences in the ileal flow of bacterial $N$ in growing pigs given increasing levels of purified NDF from wheat bran to a maizestarchsoya isolate-based dict. It seems that other casily fermentable energy sources were available to a sufficient extent for bacterial metabolism in digesta of the small intestine. Thus, more bacterial $\mathrm{N}$ passing through the ileum in diets with a higher protein level.

\section{Endogenous $N$}

The remarkable differences in ileal endogenous $\mathrm{N}$ losses between miniature pigs and domestic pigs were surprising. To some extent, these variations may be 
explained by different ages of the pigs and/or by the different batches of feed components which were used in the two parts of this experiment. The only small differences of the ileal endogenous $\mathrm{N}$ loss between the diets with and without fish meal support the assumption of Boisen and Moughan (1996) that the endogenous $\mathrm{N}$ in ileal digesta loss was induced primarily by the non-protein nitrogen of the feed arising from the digestion of protein.

The results in Table 6 indicate also that endogenous $\mathrm{N}$ bound to protein (TCAprecipitable endogenous $\mathrm{N}$ ) was predominantly recovered in bacteria. The nearly same amounts of endogenous $\mathrm{N}$ associated with bacteria passing through the ileum, determined in both treatments, demonstrate that endogenous $\mathrm{N}$ represents an casily available $\mathrm{N}$ source for bacterial protein synthesis at both levels of $\mathrm{N}$ intake.

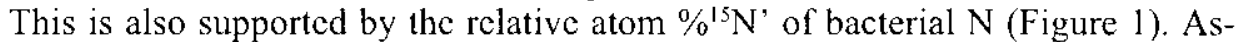
suming that bacterial $\mathrm{N}$ is a part of TCA-precipitable $\mathrm{N}$ and the same contribution of endogenous $\mathrm{N}$ to both $\mathrm{N}$-fractions, the atom $\%{ }^{15} \mathrm{~N}$ ' of both $\mathrm{N}$-fractions must have been similar. The higher ${ }^{15} \mathrm{~N}$-enrichment of bacterial $\mathrm{N}$ compared to TCAprecipitable $\mathrm{N}$ in ileal digesta indicate a higher proportion of endogenous $\mathrm{N}$ in bacterial $\mathrm{N}$ compared to TCA-precipitable $\mathrm{N}$. Taking into account that the ${ }^{15} \mathrm{~N}$ enrichments of bacterial and total $\mathrm{N}$ are similar (Tables 3 and 4), this means that a part of endogenous $\mathrm{N}$ associated with bacteria originate from TCA-soluble $\mathrm{N}$ which was less diluted by unlabelled dietary $\mathrm{N}$ than TCA-precipitable $\mathrm{N}$, especially in pigs received the diets without fish meal. There was a typical postprandial rhythm of time course of the relative atom $\%{ }^{15} \mathrm{~N}$ ' in bacterial $\mathrm{N}$ characterized by high values $4 \mathrm{~h}$ after feeding. Taking into account a passage peak of digesta to the ilcum between 4 to $8 \mathrm{~h}$ determined by maximum concentration of marker in ileum digesta (Drochner, 1984; Potkins et al., 1991) it can be derived that the proportion of endogenous $\mathrm{N}$ associated with bacteria was increased $12 \mathrm{~h}$ after feeding. At this time the amount of available dietary $\mathrm{N}$ in the small intestine is low under present conditions of feeding. It seems that the bacterial incorporation of endogenous $\mathrm{N}$ is an additional reason for the finding, that different levels of protein intake did not affect the endogenous $\mathrm{N}$ losses determined by the ${ }^{15} \mathrm{~N}$-dilution technique. On the other hand, the amounts of bacterial $\mathrm{N}$ at the distal ileum decreased though proportional higher incorporation of endogenous $\mathrm{N}$ in pigs received the diets without fish meal. Obviously, less dietary nitrogen was available for the bacterial protein synthesis compared to the diets with fish meal.

The contribution of endogenous $\mathrm{N}$ associated with bacterial $\mathrm{N}$ to total endogenous $\mathrm{N}$ in ileal digesta was higher compared to the valuc of Lien et al. (1997 b) who reported 0.25 for pigs given a barley diet. This difference may be explained by individual and dietary factors as well as different ${ }^{15} \mathrm{~N}$-dilution techniques concerning the ${ }^{15} \mathrm{~N}$-tracer, indicator pool and collection of digesta during or after the ${ }^{15} \mathrm{~N}$-labelling period. Further investigations are needed to determine whether endogenous $\mathrm{N}$ associated with bacteria in ileal digesta is affected by dietary factors. Different percentages of bacterial $\mathrm{N}$ of endogenous origin on total endogenous $\mathrm{N}$ may be important for the amino acid composition of endogenous protein in ileal digesta. 


\section{REFERENCES}

Ahrens F., Kaufmann W., 1985. Messungen zur Fermentation im Dickdarm am Modell Miniaturschwein unter besonderer Berücksichtigung der Eiweissumsetzungen. Z. Tierphysiol., Tierernähr., Futtermittelk. 53, 150-169

Bartelt J., Bergner H., Drochner W., Kijora C., Götz K.-P., 1994. Untersuchungen zum Einfluß einer unterschiedlichen Protein- und Faseraufnahme auf den ilealen Fluss an endogenem Protein bei ${ }^{15} \mathrm{~N}$-markierten Schweinen. Arch. Anim. Nutr. 46, 305-319

Bergner H., Betzin B., 1979. Untersuchungen zum Futterwert von Strohmehl in der Schweineernährung. 1. Verdaulichkeit der Nährstoffe und N-Bilanz nach Fütterung von teilhydrolysiertem Strohmehl. Arch. Tierernähr. 29, 119-128

Bergner H., Simon O., Zebrowska T., Münchmeyer R., 1986. Studies on the secretion of amino acids and urea into the gastrointestinal tract of pigs. 3. Secretion of urea determined by continuous intravenous infusion of ${ }^{15} \mathrm{~N}$-urea. Arch. Anim. Nutr. 36, 479-490

Boisen S., Moughan P.J., 1996. Dietary influences on endogenous ileal protein and amino acid loss in the pig. A review. Acta Agric. Scand. Sect A, Anim. Sci. 46, 154-164

Buraczewska L., 1979. Secretion of nitrogen compounds in the small intestine of pigs. Acta Physiol. pol. $32,319-326$

De Lange C.F.M., Souffrant W.B., Sauer W.C., 1990. Real ileal protein and amino acid digestibilities in feedstuffs for growing pigws as determined with the ${ }^{15} \mathrm{~N}$-isotope dilution technique. J. Anim. Sci. $68,409-418$

Drochner W., 1984. Einfluß wechselnder Rohfaser- und Pektingabegehalte im Futter auf einige praecaecale und postileale Verdaungsvorgänge beim wachsenden Schwein. Fortschr. Tierphysiol., Tierenähr. Heft 14, 1-125

Drochner W., Hazem S.A., Tucker R., 1987. Experimental methods. In Aspects of digestion in the large intestine of the pig. Advan. Anim. Physiol. Anim. Nutr. 17, 7-14

Drochner W., Hogenkamp D., Sauer W., Mosenthin R., 1997. Postimplantative distension of cannulas, a new method for permanent small intestine fistulation of young piglets. In: J.P. Laplace, C. Fevrier, A. Barbeau (Editors), Proceedings of the 7th International Symposium on Digestive Physiology in Pigs. Saint Malo (France), EAAP Puplication No. 88, pp. 66-70

Dufva G.S., Bartley E.E., Arambel M.J.. Nagaraja T.G., Dennis S.M., Galitzer S.J., Dayton A.D., 1982. Diaminopimelic acid content of feeds and rumen bacteria and its usefulness as a rumen bacterial marker. J.Dairy Sci. 65, 1754-1759

Grala. W., Verstegen M.V.A., Jansman A.J.M., H Juisman, J., Van Lceuwen, P., 1998. Ileal apparent protein and amino acid digestibilities and endogenous nitrogen losses in pigs led soybean and rapeseed products. J. Anim. Sci. 76, 557-568

Herrmann U., Krawielitzki K.. Smulikowska S., Schadereit R., 1986. Zur Bestimmung des endogenen Stickstofls im Kot mit Hilfe der Isotopentechnik. Arch. Anim. Nutr. 36, 857-865

Hernández M., Simon O., Bergner H., 1981. Eine neue Methode zur Prüfung der Qualität von Nahrungsproteinen für den Erhaltungsstoffwechsel. 3. Methodische Untersuchungen an ${ }^{15} \mathrm{~N}$-markierten ausgewachsenen Ratten. Arch. Tierernähr. 31, 651-660

Huisman J., Heinz T., van der Poel A.F.B., van Leeuwen P., Souffrant W.B., Verstegen M.W.A., 1992. True protein digestibility and amounts of endogenous protein measured with the ${ }^{15} \mathrm{~N}$-dilution technique in piglets led on peas (Pisum sativum) and common beans (Phaseolus vulgaris). Brit. J. Nutr. 68, 101-110

Jansman A.J.M., Verstegen M.W.A., Huisman J., Van den Berg J.W.O., 1995. Effect of hulls of faba beans (Vicia faba L.) with low or high content of condensed tannins on apparent ileal and fecal 
digestibility of nutrients and excretion of endogenous protein in ileal digesta and feces of pigs. J. Anim. Sci. 73, 118-127

Krawielitzki K., Żebrowska T., Schadereit R., Kowalczyk J., Hennig U., Wünsche J., Herrmann U., 1990. Determining of nitrogen absorption and nitrogen secretion in different sections of the pig's intestine by digesta exchange between ${ }^{15} \mathrm{~N}$-labelled and unlabelled animals. Arch. Anim. Nutr. 40, 25-37

Leterme P., Sève B., Théwis A., 1998. The current ${ }^{15} \mathrm{~N}$-leucine infusion technique is not suitable for quantitative measurements of ileal endogenous amino acid flow in pigs. J. Nutr. 128, 1961-1968

Lien K.A., Sauer, W.C., Mosenthin R., Souffrant W.B., Dugan M.E.R., 1997a. Evaluation of the ${ }^{15} \mathrm{~N}$-isotope dilution technique for determination the recovery of endogenous protein in ileal digesta of pigs. Effect of dilution in the precursor pool for endogenous nitrogen secretion. J. Anim. Sci. 75, 148-158

Lien K.A., Sauer, W.C., Dugan M.E.R., 1997b. Evaluation of the ${ }^{15} \mathrm{~N}$-isotope dilution technique for determination the recovery of endogenous protein in ileal digesta of pigs. Effect of the pattern of blood sampling, precursor pools and isotope dilution technique. J. Anim. Sci. 75, 159-169

Makkink C.A., Heinz T., Souffrant W.B., Verstegen M.W.A., 1997. Endogenous N losses at the terminal ileum of young piglets fed diets based on four different protein sources. J. Anim. Feed Sci. 6, 219-234

Mosenthin R., Sauer W.C., 1991. The effect of source of fiber on secretions and on amino acid digestibility in the pig. J. Anim. Physiol. Anim. Nutr. 65, 45-52

Mosenthin R., Sauer W.C., De Lange C.F.M., 1992. Tracer studies of urea kinetics in growing pigs. 1. The effect of intravenous infusion of urea on urea recycling and the site of urea secretion into the gastrointestinal tract. J. Anim. Sci. 70, 3458-3466

Mosenthin R., Sauer W.C., Ahrens F., 1994. Dietary pectin's effect on ileal and fecal amino acid digestibility and exocrine pnacreatic secretions in growing pigs. J. Nutr. 124, 1222-1229

Moughan P.J., Buttery P.I., Essex C.P., Soar J.B., 1992. Evaluation of the isotope dilution technique for determining ileal endogenous nitrogen excretion in the rat. J. Sci. Food Agric. 58, 165-172

Naumann C., Bassler, R., 1976. Die chemische Untersuchung von Futtermitteln, Methodenbuch. Band 3 mit Ergänzungslieferungen 1983, 1988, 1993, 1997. Verlag VDLUFA, Darmstadt

Potkins Z.V., Lawrence T.L.J. Thomlinson J.R., 1991. Effect of structural and non-structural polysaccharides in the diet of the growing pig on gastric emptying rate and rate of passage of digesta to the terminal ileum and through the total gastrointestinal tract. Brit. J. Nutr. 65, 391-413

Schulze H., 1994. Endogenous ileal nitrogen losses in pigs - dietary factors. Ph.D. Thesis. Wageningen Agricultural University

Schulze H., Van Leeuwen P., Verstegen M.W.A., Huisman J., Souffrant W.B., Ahrens F., 1994. Effect of level of dietary neutral detergent fiber on ileal apparent digestibility and ileal nitrogen losses in pigs. J. Anim. Sci. 72, 2362-2368

Schulze H., Van Leeuwen P., Verstegen M.V.A., Van den Berg J.W.O., 1995. Dietary level and source of neutal detergent fiber and ileal endogenous nitrogen flow in pigs. J. Anim. Sci. 73, 441-448

Simon O., 1989. Metabolism of proteins and amino acids. In: H.D. Bock, A.G. Low, O. Simon, T. Żebrowska (Editors). Protein Metabolism in Farm Animals. Oxford University Press and VEB Deutscher Landwirtschaftsverlag, Berlin, pp. 273-366

Simon O., Bergner H., Münchmeyer R., Żebrowska T., 1982. Studies on the range of tissue protein synthesis in pigs. The effect of thyroid hormones. Brit. J. Nutr. 48, 571-582

Simon O., Bergner H., Partridge I.G., 1987. Estimation of the endogenous N proportions in ileal digesta and faeces in ${ }^{15} \mathrm{~N}$-labelled pigs. Arch. Anim. Nutr. 37, 851-859 
Simon O., Zebrowska T., Bergner H., Münchmeyer R., 1983. Investigations on the pancreatic and stomach secretion in pigs by means of continuous infusion of ${ }^{14} \mathrm{C}$-amino acids. Arch. Tierernähr. $33,9-22$

Souffrant W.B., Rérat A., Laplace J.P., Darcy-Vrillon B., Köhler R., Corring T., Gebhardt G., 1993. Exogenous and endogenous contributions to nitrogen fluxes in the digestive tract of pigs fed a casein diet. 1II. Recycling of endogenous nitrogen. Reprod. Nutr. Develop. 33, 373-382

Wu G., 1995. Urea synthesis in enterocytes of developing pigs. Biochem. J. 312, 717-723

Wutzke K., Heine W., Drescher U., Richter I., Plath C., 1983. ${ }^{15} \mathrm{~N}$-labelled yeast protein, a valid tracer for calculating whole-body protein parameters in infants. A comparison between $\left[{ }^{15} \mathrm{~N}\right]$-yeast protein and $\left[{ }^{15} \mathrm{~N}\right]$-glycine. Hum. Nutr.: Clin. Nutr. 37C, 317-327

Wünsche J., Völker T., Souffrant W.-B., Borgmann E., 1991. Bestimmung der Bakterien-N-Anteilc in Kot und unterschiedlich gewonnenem Ileumchymus von Schweinen. Arch. Anim. Nutr. 41, $703-716$

\section{STRESZCZENIE}

Oznaczenie azotu endogennego $w$ bakteriach treści jelita biodrowego świń żywionych dawkami zbożowymi z (lub bez) dodatkiem mączki rybnej oraz różnymi dodatkami wlókna przy zastosowaniu techniki rozcieńczeń ${ }^{15} \mathrm{~N}$

Cztery miniaturowe świnie Göttinger i 5 świń Landrace, o podobnej masie ciała z kaniulami mostkowymi w końcowym odcinku jelita biodrowego, żywiono mieszanką zbożową z dodatkiem (Grupa 1) lub bez (Grupa 2) mączki rybnej. Dicty zawicrały zwiększającą się ilość częściowo zhydrolizowanej mączki ze słomy i pektyny $(2: 1 \mathrm{w} / \mathrm{w})$. W 2, 5 i 7 dniu po 5 dniach podawania $z$ dawką ${ }^{15} \mathrm{NH}_{4} \mathrm{Cl}$ określano ilość azotu endogennego opuszczającego jelito biodrowe z wielkości procentowego nadmiaru ${ }^{15} \mathrm{~N} w$ azocie moczu, użytego jako wskaźnik. Wzbogacenic w ${ }^{15} \mathrm{~N}$ azotu moczu, frakcji $\mathrm{N}$-rozpuszczalnego i $\mathrm{N}$-nierozpuszczalnego w TC $\Lambda$ osocza krwi, w trzustce i jelicie cienkim było niemal takie same. Udział azotu endogennego w azocie ogólnym, frakcji azotu nierozpuszczalnego w TCA i azotu bakteryjnego w jelicie biodrowym nie ulegał zmianom w trzech kolejnych okresach kolekcji. Wydaje się, że azot moczu jest, w warunkach przeprowadzonego doświadczenia, najłatwicjszym i właściwym wskaźnikiem oznaczania azotu endogennego. Ani dodatek włókna ani ilość pobranego azotu nie wpływały na ilość azotu endogennego opuszczającego jelito biodrowe. $\mathrm{Na}$ ilość opuszczającego jelito biodrowe bakteryjnego azotu endogennego, w przeciwieństwie do ilości bakteryjnego azotu ogólnego, nie wpływała ilość pobranego z paszą białka. Udział azotu endogennego zawartego $w$ bakteriach $w$ ogólnym azocie endogennym wynosił od 0,43 do $0.56 \mathrm{u}$ zwierząt Grupy I i od 0.40 do 0,53 w Grupie 2, natomiast udział azotu endogennego w ogólnym azocie bakteryjnym wynosił od 0,48 do 0,57 w Grupie 1 , a od 0,56 do 0,79 w Grupie II. W podsumowaniu badań stwierdzono, że azot endogenny był łatwo przyswajalny przez bakterie przy obydwóch poziomach pobranja przez zwierzęta białka z paszą. 